\title{
REHABILITASI MEDIK PADA POLIOMIELITIS
}

\author{
Lely M. Pontoh \\ Engeline Angliadi
}

\author{
Program Studi Ilmu Kedokteran Fisik dan Rehabilitasi \\ Fakultas Kedokteran Universitas Sam Ratulangi Manado \\ Email: lelymaryanti@yahoo.co.id
}

\begin{abstract}
Poliomyelitis (polio, infantile paralysis) is caused by a type of virus that has three serotypes: PV1, PV2, and PV3. Spreading of polio viruses from person-to-person is by faecal-oral route. Typical manifestations of poliomyelitis occur when the viruses spread, infect, and replicate in the cells of the central nervous system. The characteristic and most severe form of clinical manifestation of polio infection is paralytic polio that usually presents as asymmetrical permanent paralysis of the leg. The diagnosis of polimyelitis is confirmed based on anamnesis, physical examination, and additional examination. Medical rehabilitation programs are applied during acute, sub acute, recovery, and chronic phases.
\end{abstract}

Keywords: poliomyelitis, virus, paralysis, diagnosis, medical rehabilitation

\begin{abstract}
Abstrak: Poliomielitis (polio, paralisis infantil) disebabkan oleh sejenis virus yang terdiri dari 3 serotipe, yaitu: PV1, PV2, dan PV3. Cara penularan penyakit ini dari manusia ke manusia melalui jalur fekal-oral. Manifestasi poliomielitis disebabkan karena penyebaran virus yang menginfeksi dan bereplikasi di dalam sel-sel sistem saraf pusat. Karakteristik dan bentuk manifestasi klinik yang paling berat dari infeksi polio ialah polio paralitik yang biasanya menyebabkan paralisis permanen asimetris pada tungkai. Diagnosis poliomielitis ditegakkan melalui anamnesis, pemeriksaan fisik, dan pemeriksaan penunjang. Program rehabilitasi medik diterapkan pada fase akut, fase sub akut, fase penyembuhan, dan fase kronis poliomielitis.
\end{abstract}

Kata kunci: poliomielitis, virus, paralisis, diagnosis, rehabilitasi medik

Poliomielitis (polio, paralisis infantile) adalah penyakit menular oleh infeksi virus yang bersifat akut. ${ }^{1,2}$ Predileksi virus ialah merusak sel-sel neuron motorik kornu anterior masa kelabu medula spinalis (anterior horn cells of the spinal cord) dan batang otak (brain stem) yang berakibat kelemahan atau kelumpuhan otot (paralisis flaksid akut) dengan distribusi dan tingkat yang bervariasi serta bersifat permanen.,

Tujuan rehabilitasi pada penderita poliomielitis ialah meningkatkan kualitas hidup dan mempertahankan kemampuan fungsional yang ada agar penderita memiliki produktivitas sesuai kemampuan. ${ }^{5}$ Rehabilitasi diharapkan dapat mengurangi dampak dari disabilitas atau kecacatan serta memungkinkan penyandang cacat untuk berpartisipasi secara aktif dalam lingkungan keluarga atau masyarakat. ${ }^{6}$

\section{POLIOMIELITIS}

\section{Epidemiologi, etiologi, dan transmisi}

Poliomielitis adalah suatu penyakit paralisis atau lumpuh yang disebabkan oleh 
virus. ${ }^{7}$ Penyakit ini tersebar di seluruh dunia dan manusia merupakan satu-satunya reservoir untuk poliomielitis. ${ }^{3}$ Poliomielitis sedikit lebih banyak menyerang anak lakilaki dibandingkan anak perempuan, dan lebih sering dialami oleh anak-anak yang tidak mendapatkan vaksinasi, terutama bagi mereka yang tinggal di daerah yang penduduknya padat dan dengan sanitasi yang buruk. ${ }^{8}$

Poliomielitis disebabkan oleh infeksi dari genus enterovirus yang dikenal dengan poliovirus. Terdapat tiga serotipe dari poliovirus, yaitu: poliovirus tipe 1 (Brunhilde/PV1), tipe 2 (Lansing/PV2), dan tipe 3 (Leon/PV3). ${ }^{3}$ Transmisi penyakit ini sangat mudah lewat oral-oral (orofaringeal) dan fekal-oral (intestinal). ${ }^{9}$ Polio sangat infeksius antara 7-10 hari sebelum dan sesudah timbulnya gejala, tetapi transmisinya mungkin terjadi selama virus berada di dalam saliva atau feses. ${ }^{10}$

\section{Patofisiologi}

Poliovirus masuk kedalam tubuh melalui mulut, menginfeksi sel yang pertama ditemuinya, yaitu di faring dan mukosa saluran cerna. Virus ini masuk dan berikatan dengan immunoglobulin-like receptor, yang dikenal sebagai reseptor poliovirus atau CD 155, pada membran sel. ${ }^{10}$ Di dalam sel-sel saluran cerna, virus ini bertahan selama sekitar 1 minggu, kemudian menyebar ke tonsil, jaringan limfoid saluran cerna dan kelenjar limfa mesenterik dan servikal dimana virus ini berkembang biak. Selanjutnya, virus ini masuk ke dalam aliran darah. Poliovirus dapat bertahan dan berkembang biak dalam darah dan kelenjar limfa untuk waktu lama, kadang-kadang hingga 17 minggu. ${ }^{11}$

\section{Jenis-jenis poliomielitis}

\section{Polio paralitik}

Denervasi jaringan otot skelet sekunder oleh infeksi poliovirus dapat menimbulkan kelumpuhan. ${ }^{12}$ Tanda-tanda awal polio paralitik ialah panas tinggi, sakit kepala, kelemahan pada punggung dan leher, kelemahan asimetris pada berbagai otot, peka dengan sentuhan, susah menelan, nyeri otot, hilangnya refleks superfisial dan dalam, parestesia, iritabilitas, konstipasi, atau sukar buang air kecil. Kelumpuhan umumnya berkembang 1-10 hari setelah gejala awal mulai timbul Prosesnya berlangsung selama 2-3 hari, dan biasanya komplit seiring dengan turunnya panas. ${ }^{13}$

\section{Polio spinal}

Polio spinal adalah tipe poliomielitis paralisis yang paling sering akibat invasi virus pada motor neuron di kornu anterior medula spinalis yang bertanggung jawab pada pergerakan otot-otot, termasuk otototot interkostal, trunkus, dan tungkai. ${ }^{14}$ Kelumpuhan maksimal terjadi cukup cepat (2-4 hari), dan biasanya timbul demam serta nyeri otot. ${ }^{15}$ Virus dapat merusak otototot pada kedua sisi tubuh, tetapi kelumpuhannya paling sering asimetris. Kelumpuhan seringkali lebih berat di daerah proksimal dari pada distal. ${ }^{16}$

\section{Polio bulbar}

Terjadi kira-kira 2\% dari kasus polio paralitik. Polio bulbar terjadi ketika poliovirus menginvasi dan merusak sarafsaraf di daerah bulbar batang otak. ${ }^{4}$ Destruksi saraf-saraf ini melemahkan otototot yang dipersarafi nervus kranialis, menimbulkan gejala ensefalitis, dan menyebabkan susah bernafas, berbicara, dan menelan. ${ }^{9}$ Akibat gangguan menelan, sekresi mukus pada saluran napas meningkat, yang dapat menyebabkan kematian. $^{13}$

\section{Polio bulbospinal}

Kira-kira 19\% dari semua kasus polio paralitik yang memberikan gejala bulbar dan spinal; subtipe ini dikenal dengan polio respiratori atau polio bulbospinal. ${ }^{4}$ Poliovirus menyerang nervus frenikus, yang mengontrol diafragma untuk mengembangkan paru-paru dan mengontrol otot-otot yang dibutuhkan untuk menelan. ${ }^{16}$

\section{Gejala klinik}

Gejala klinik bermacam-macam dan digolongkan sebagai berikut: ${ }^{17}$ 
1. Jenis asimtomatis

Setelah masa inkubasi 7-10 hari, tidak terdapat gejala klinik sama sekali karena daya tahan tubuh cukup baik. Jenis ini banyak terdapat waktu epidemi.

2. Jenis abortif

Timbul mendadak langsung beberapa jam sampai beberapa hari. Gejala seperti infeksi virus lainnya, yaitu: malaise, anoreksia, nausea, muntah, nyeri kepala, nyeri tenggorokan, konstipasi dan nyeri abdomen.

3. Jenis non-paralitk

Gejala kliniknya hampir sama dengan poliomielitis abortif, hanya nyeri kepala, nausea, dan muntah lebih hebat. Terdapat tanda-tanda rangsangan meningeal tanpa adanya kelumpuhan. Suhu bisa naik sampai $38-39^{\circ} \mathrm{C}$ disertai nyeri kepala dan nyeri otot. Bila penderita ditegakkan, kepala akan terjatuh kebelakang (head drops). Bila penderita berusaha duduk dari sikap tidur maka kedua lututnya ditekuk dengan menunjang kebelakang dan terlihat kekakuan otot spinal (tripod sign).

4. Jenis paralitik

Gejala kliniknya sama seperti pada jenis non-paralitik, kemudian disertai kelumpuhan yang biasanya timbul 3 hari setelah stadium preparalitik.

\section{Diagnosis}

Diagnosis poliomielitis paralitik ditegakkan berdasarkan anamnesis yaitu adanya kelumpuhan flaksid yang mendadak pada salah satu atau lebih anggota gerak dengan refleks tendon yang menurun atau tidak ada pada anggota gerak yang terkena, yang tidak berhubungan dengan penyebab lainnya, dan tanpa adanya gangguan sensori atau kognitif. ${ }^{18}$

Virus polio dapat diisolasi dan dibiakkan dari bahan hapusan tenggorok pada minggu pertama penyakit, dan dari tinja sampai beberapa minggu. Bila pemeriksaan isolasi virus tidak dapat dilakukan, maka dipakai pemeriksaan serologi berupa tes netralisasi dengan memakai serum pada fase akut dan konvalesen. Selain itu bisa juga dilakukan pemeriksaan complement fixation (CF). Diagnosis laboratorik biasanya berdasarkan ditemukannya poliovirus dari sampel feses atau dari hapusan faring. Antibodi dari poliovirus dapat didiagnosis, dan biasanya terdeteksi di dalam darah pasien yang terinfeksi. Hasil analisis cairan serebrospinal yang diambil dari pungsi lumbal didapati adanya peningkatan jumlah leukosit serta protein juga sedikit meningkat. Dapat juga dilakukan pemeriksaan khusus yaitu kecepatan hantar saraf dan elektromiografi. ${ }^{4}$

Diagnosis banding ialah meningitis tuberkulosis, sindroma Guillain-Barre, mieltis transversa, dan ensefalitis. ${ }^{19}$

\section{Komplikasi}

Beberapa komplikasi yang sering ditemukan, yaitu: equinus foot (club foot), deformitas, gangguan pergerakan sendi, skoliosis, osteoporosis, neuropati. dan komplikasi akibat tirah baring lama. ${ }^{20-22}$

\section{Prognosis}

Prognosis tergantung pada beratnya penyakit. ${ }^{4}$ Pemulihan motorik pada poliomielitis umumnya cukup baik. Pada kasus polio spinal, bila sel-sel saraf rusak total maka kelumpuhan dapat menetap. ${ }^{23}$ Prognosis buruk pada bentuk bulbar. Kematian biasanya terjadi karena kegagalan fungsi pusat pernapasan atau infeksi sekunder pada jalan napas. ${ }^{3}$

\section{Pencegahan}

Pencegahan dapat dilakukan dengan pemberian imunisasi aktif dan menghindari daerah endemis. ${ }^{17}$

\section{PENATALAKSANAAN}

Terdapat beberapa hal penting yang perlu diperhatikan, yaitu: ${ }^{24,25}$

1. Istirahat selama fase akut.

2. Penderita diisolasi selama fase akut.

3. Terapi simtomatik untuk meringankan gejala. 
4. Dilakukan fisioterapi untuk mengurangi kontraktur, atrofi, dan atoni otot. Otot-otot yang lumpuh harus dipertahankan pada posisi untuk mencegah deformitas. Dua hari setelah demam menghilang dilakukan latihan gerakan pasif dan aktif.

5. Akupunktur dapat dilakukan dengan hasil yang cukup memuaskan

6. Terapi ortopedik dilakukan bila terjadi cacat karena kontraktur dan subluksasi akibat terkenanya otot di sekitar sendi dan lain-lain.

\section{Program rehabilitasi medik}

Fase akut (<2 minggu) ${ }^{6}$

Ditekankan tindakan suportif dan upaya pencegahan kerusakan sel-sel kornu anterior medula spinalis yang permanen serta mencegah kecacatan, yang meliputi:

- Istirahat di tempat tidur (sebaiknya dirawat di rumah sakit) dan diet yang adekuat

- Aktivitas fisik dan trauma dihindari selama fase preparalitik

- Karena adanya demam dan nyeri otot, diberikan obat analgetik dan kompres hangat untuk mengurangi nyeri dan spasme otot

- Posisi tidur diatur yang nyaman bagi anak dan cegah kontraktur, kalau perlu dengan splinting. Pada awalnya otototot terasa nyeri, sehingga anak menolak untuk meluruskan tungkainya. Secara lembut dan pelan luruskan lengan dan tungkainya sehingga anak berbaring dalam posisi yang baik. Buat lengan, pinggul (hip, dan tungkai selurus mungkin. Berikan penyokong pada kaki. Untuk mengurangi nyeri, letakkan bantalan di bawah lutut.

\section{Fase subakut (2 minggu - 2 bulan) ${ }^{5}$}

Latihan pasif atau latihan aktif yang ringan dapat mulai diberikan. Pada akhir fase ini, penderita bisa di latih berdiri.

\section{Fase penyembuhan (2 bulan - 2 tahun) ${ }^{5}$}

Pada fase ini dilakukan pemeriksaan manual muscle test (MMT) pertama, untuk menentukan pemberian jenis ortosis pada anggota gerak dengan kekuatan otot $<3$.

Jenis ortosis yang diberikan tergantung pada letak otot yang lemah (MMT <3), misalnya:

- Bila kekuatan otot-otot pinggul <3, ortosis yang dipakai HKAFO

- $\quad$ Bila terdapat kelemahan otot-otot lutut maka yang dipakai KAFO

- Bila terdapat kelemahan otot-otot pergelangan kaki, maka yang dipakai AFO

Evaluasi kekuatan otot (MMT) dilakukan setiap 3 bulan. Fase penyembuhan bisa terjadi sampai 2 tahun sehingga bila dalam kurun waktu tersebut terdapat perbaikan kekuatan otot, maka ortosis bisa diubah menjadi yang lebih sederhana atau bahkan ortosisnya bisa dilepas.

\section{Fase kronis (> 2 tahun) ${ }^{5}$}

Bila sampai 2 tahun setelah lumpuh tidak terjadi perbaikan kekuatan otot, maka ortosis dipakai seumur hidup untuk mencegah komplikasi yang lain, misalnya: karena adanya perbedaan panjang tungkai dan tanpa koreksi akan menimbulkan skoliosis, atau karena adanya kekuatan otot pergelangan kaki yang tidak seimbang tanpa koreksi, maka akan terjadi pes equinus.

Kadang-kadang pada fase ini memerlukan tindakan operasi bila terdapat pemendekan otot atau kontraktur sendi yang tidak dapat diperbaiki dengan tindakan fisioterapi maupun dengan ortosis.

Pada penderita poliomielitis selain dilakukan latihan penguatan untuk otot-otot yang mengalami kelemahan, juga perlu dilakukan latihan penguatan pada otot-otot yang tidak mengalami kelemahan, terutama otot-otot ekstremitas superior, untuk persiapan penggunaan ortosis atau alat bantu seperti wheelchair dan crutches (Gambar 1).

\section{Ortosis untuk penderita poliomielitis}

Terdapat beberapa jenis ortosis untuk penderita poliomielitis, yaitu: ${ }^{25}$ 

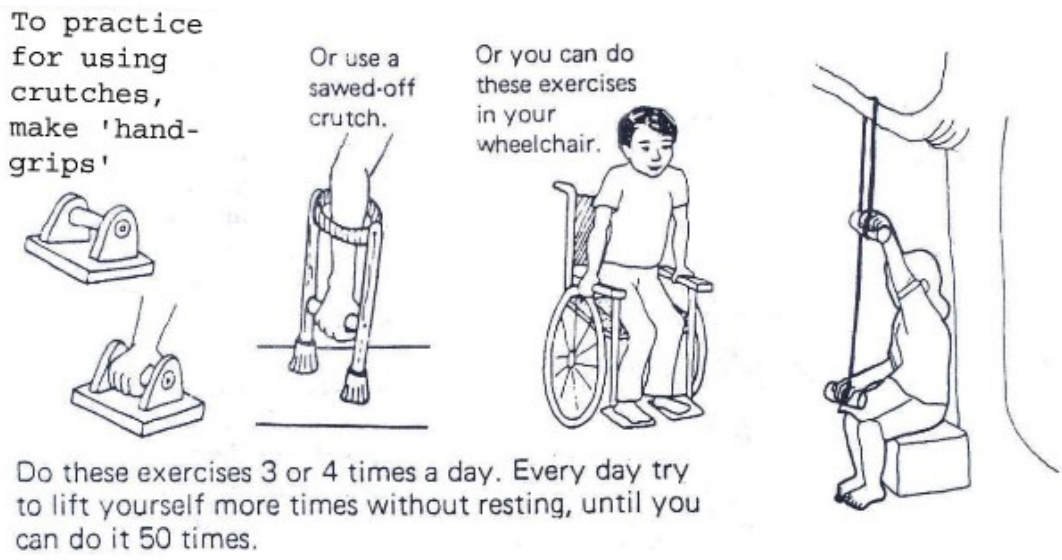

Gambar 1. Latihan penguatan ekstremitas superior. Sumber: Werner D, $2007 .^{8}$

1. Hip knee ankle foot orthosis (HKAFO): yaitu alat penguat anggota gerak bawah(tungkai) yang berfungsi untuk membantu mobilitas post polio paralysis, genu valgum poliomielitis. HKAFO ini dibuat dari bahan polietilen yang di rangkai dengan side bar duraluminium/stainless steel.

2. Knee ankle foot orthosis (KAFO): terdapat berbagai jenis KAFO dilihat dari desain dan fungsinya pada pergelangan kaki dan lutut. Sebelum memutuskan jenis KAFO yang akan dipakai pasien, harus diketahui tempat tinggal, jenis pekerjaan, keluhan, perawatan lain yang diinginkan, jenis alas kaki yang tidak cocok, cara berjalan, lingkup gerak sendi, kekuatan otot, kepekaan, propriosepsi, dan panjang kaki.

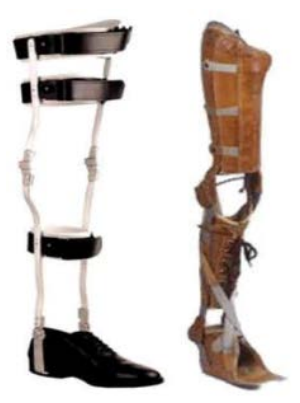

Then

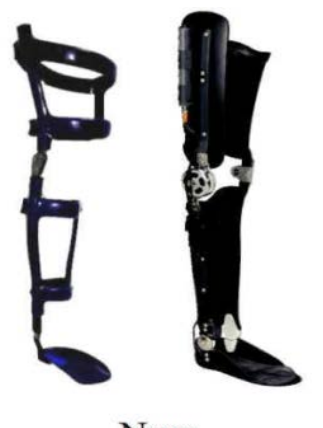

Now
Gambar 2. Knee ankle foot orthosis. Sumber: Kuspito. ${ }^{25}$
Kebutuhan pasien akan KAFO dilihat berdasarkan kelumpuhan, kelemahan otot, ketidakseimbangan otot, luka bakar, kontraktur, spastisitas, kaki yang tidak sama panjang. Tujuan utamanya ialah memaksimalkan kualitas hidup pasien dengan menyediakan alat ortosis dan mengajarkan manajemen ortosis yaitu cara memakai serta merawat alat tersebut.

3. Ankle foot orthosis (AFO): merupakan salah satu jenis alat yang berfungsi sebagai penguat anggota gerak. Alat bantu ini di desain dengan memperhatikan aspek patologis, biomekanis dan mekanis. AFO dibuat dari bahan polyetilene yang dilapisi soft foam untuk kenyamanan pada saat dipakai pasien. Tujuan AFO ialah untuk menyediakan dukungan eksternal yang diperlukan untuk kaki dan tungkai ketika ada gangguan fisik atau kelemahan otot. Umumnya AFO berguna untuk mengendalikan ketidakstabilan di ekstremitas bawah dengan mempertahankan keselarasan dan mengendalikan gerakan yang terjadi pada ankle dan telapak kaki. AFO berfungsi untuk mencegah kecacatan yang lebih lanjut; mengkoreksi kecacatan; dan mengontrol atau mengatur gerakan yang terjadi pada pergelangan kaki. 


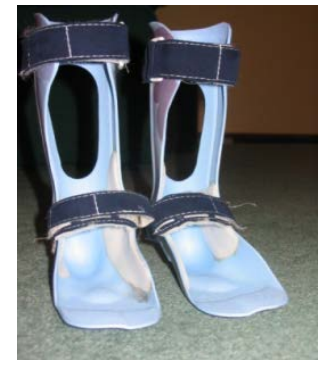

Gambar 3. Ankle foot orthosis. Sumber: Kuspito. $^{25}$

\section{Perubahan bantuan dan pertolongan terhadap anak yang menderita poliomielitis}

Terdapat beberapa jenis latihan dan ortosis untuk penderita poliomielitis anak, yaitu: $^{8}$

1. Latihan lingkup gerak sendi

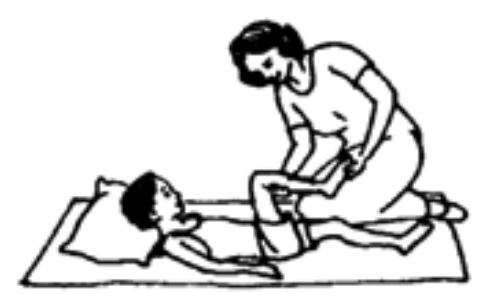

2. Latihan duduk dengan memakai sandaran yang membantu mencegah kontraktur

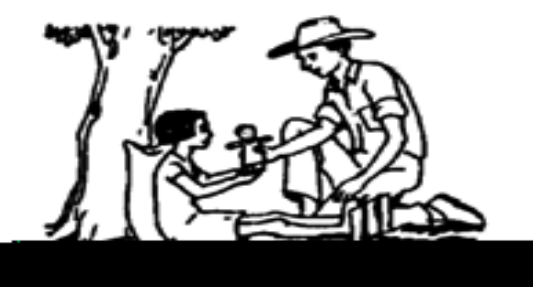

3. Latihan aktif extremitas inferior dengan bantuan, untuk meningkatkan kekuatan dan mempertahankan lingkup gerak sendi

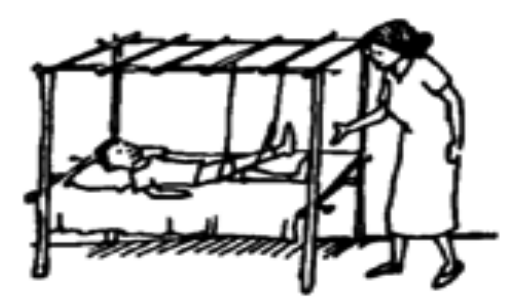

4. Latihan di dalam air, dengan berjalan, mengapung, dan berenang

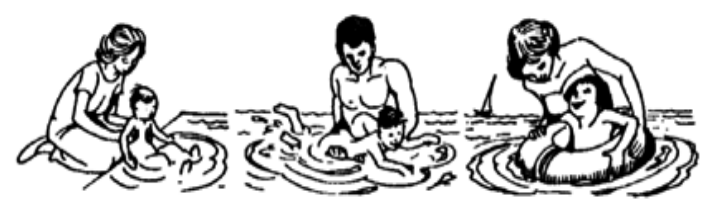

5. Wheelboard atau wheelchair dengan bantuan untuk mencegah atau mengoreksi kontraktur dini. Juga melatih lengan untuk persiapan penggunaan crutches.
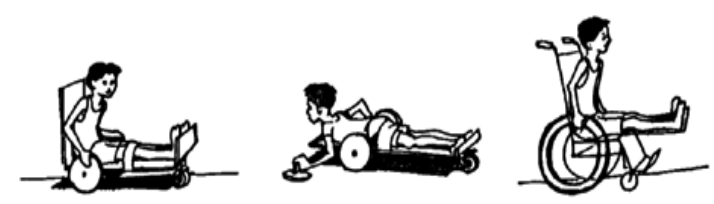

6. Penggunaan braces untuk mencegah kontraktur dan persiapan untuk berjalan

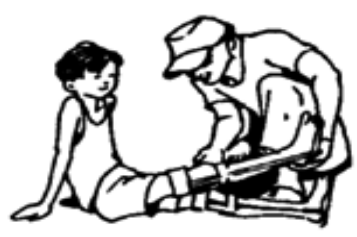

7. Latihan mulai berjalan dan untuk keseimbangan di parallel bar

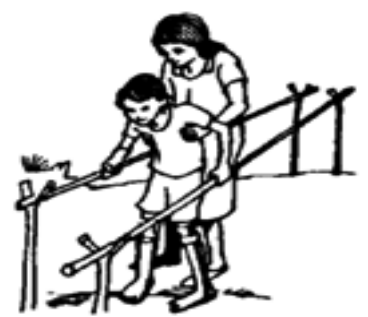

8. Berjalan dengan machine atau walker

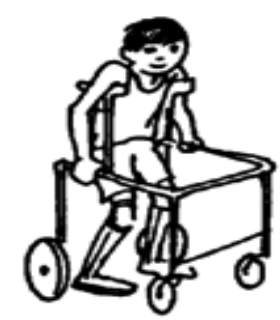


9. Menggunakan crutches yang di modifikasi seperti walker untuk keseimbangan

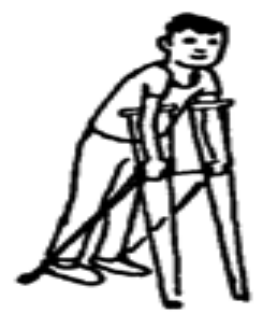

10. Menggunakan under arm crutches

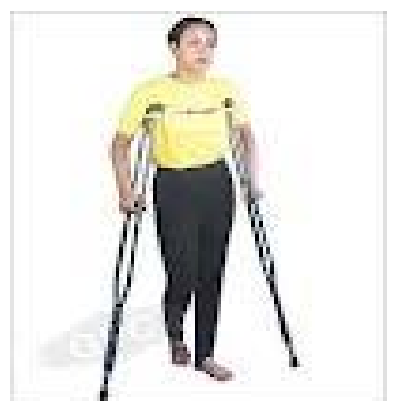

11. Menggunakan forearm cruthes

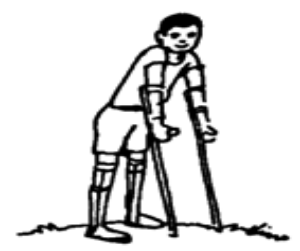

12. Menggunakan cane atau tanpa bantuan pada ekstremitas superior

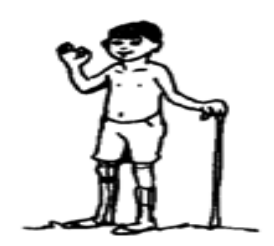

\section{SIMPULAN}

Poliomielitis adalah penyakit yang disebabkan oleh virus. Gejalanya yaitu adanya kelumpuhan flaksid mendadak pada salah satu atau lebih anggota gerak tanpa adanya gangguan sensori atau kognitif. Diagnosis dan penanganan dini penderita poliomielitis sangat diperlukan.

Tujuan rehabilitasi pada penderita poliomielitis ialah meningkatkan kualitas hidup dan mempertahankan kemampuan fungsional yang ada agar penderita memiliki produktivitas sesuai kemampuan.

\section{DAFTAR PUSTAKA}

1. Cohen JI. Enteroviruses and Retroviruses. In: Kasper DL, Braunwald E, Fauci AS, Hauser Sl, Longo DL, Jameson JL, et al. Harrison's Principles of Internal Medicine (16th ed.). New York: McGraw-Hill Professional, 2004; p. 1144-54.

2. Chamberlin SL, Narins B. The Gale Encyclopedia of Neurological Disorders. Vol. 2. Detroit: Thomson Gale. 2005. p. 1859-70.

3. Pasaribu S. Aspek diagnostik poliomielitis. Medan: Bagian Ilmu Kesehatan Anak FK USU, 2005.

4. Atkinson W, Hamborsky J, McIntyre L, Wolfe S. Poliomyelitis. Epidemiology and Prevention of Vaccine-Preventable Diseases (11th ed.). Washington DC: Public Health Foundation, 2009; p. 23144.

5. Modul Poliomielitis. Manado: Instalasi Kedokteran Fisik dan Rehabilitasi FK Unsrat Manado, 2008; p.12-8.

6. Angliadi LS. Rehabilitasi medik pada stroke. Stroke update. Manado: SMF/Instalasi Rehabilitasi Medik RSU Prof. Dr. R. D. Kandou Manado, 2001; p. 56-69.

7. Trevelyan B, Smallman-Raynor M, Cliff AD. The spatial dynamics of poliomyelitis in the United States: From epidemic emergence to vaccine-induced retreat, 1910-1971. Ann Assoc Am Geogr. 2005; 95(2):269-93.

8. Werner D. Polio, infantile paralysis. In: Disabled village children. AS guide for community health, workers, rehabilitation workers, and families (2nd ed.). Berkeley, California: Hesperian foundation: 2007; p. 59-76.

9. Todar K. Polio. Ken Todar's Microbial World. Madison: University of Wisconsin, 2006.

10. Ryan KJ, Ray CG. Enteroviruses. In: Sherris JC, Ryan KJ, Ray CG, editors. Sherris Medical Microbiology (4th ed.). New York: McGraw Hill, 2004. p. 5357. ISBN 0-8385-8529-9.

11. He Y, Mueller S, Chipman PR, Bator 
CM, Peng X, Bowman VD, et al. Complexes of Poliovirus Serotypes with Their Common Cellular Receptor, CD155. J Virol. 2003;77:4827-35.

12. Joint Committee on Vaccination and Immunisation. Poliomyelitis. In: Salisbury A, Ramsay M, Noakes K, editors. Immunisation against Infectious Disease (3rd ed.). Edinburgh: Stationery Office, 2006; p. 313-29. ISBN: 0-11322528-8.

13. Mueller S, Wimmer E, Cello J. Poliovirus and poliomyelitis: a tale of guts, brains, and an accidental event. Virus Res. 2005;111(2):175-93.

14. McNeil D. In Battle against polio, a call for a final salvo. New York Times, 2011. [cited 2012 Apr 9]. Available from: http://www.nytimes.com/2011/02/01/he alth/01polio.html?ref=science.

15. Silverstein A, Silverstein VB, Nunn LS. Polio. Diseases and people. Berkeley Heights. New york: Enslow Publisher, 2001: p. 12.

16. Professional Guide to Diseases (Professional Guide Series). Hagerstown, MD: Lippincot Williams \& Wilkins, 2005; p. 243-5. ISBN: 1-58255-3070X

17. Graves HW, Neil M, Frank W. Walsh and Hoyt's clinical neuro-ophthalmology. Hagerstown, MD: Lippincot Williams \& Wilkins. Philadelphia. 2005. p. 3264-65.

18. Sauerbrei A, Groh A, Bischoff A, Prager J, Wutzler P. Antibodies against vaccine-preventable diseases in pregnant women and their offspring in the eastern part of Germany. Med Microbiol Immunol. 2002;190:167-72.

19. Poliomielitis anterior akut. In: Kapita Selekta Kedokteran Jilid 2 (Edisi III). Jakarta: FKUI Media Aesculapius, 1996; p. 582-4.

20. Cono J, Alexander LN. Poliomyelitis. In: Vaccine Preventable Disease Surveillance Manual (3rd ed.). Atlanta: Centers for Disease Control and Prevention, 2002. p. 10-11.

21. Pasteur S. Poliomyelitis virus (picornavirus, enterovirus), after-effects of the polio, paralysis, deformations. In: Polio Eradication. Sanofi Pasteur. France, 2007.

22. Mayo Clinic Staff. Polio: Complications. Mayo Foundation for Medical Education and Research (MFMER). Scottsdale: Phoenix. 2005.

23. Neumann D. Polio: its impact on the people of the United States and the emerging profession of physical therapy. The Journal of orthopaedic and sports physical therapy. 2004;34 (8):479-92.

24. Goldberg A. Non invasive mechanical ventilation at home: building upon the tradition. Chest. 2002;121(2):321-4.

25. Kuspito. Artikel tentang kecacatan dan penanganannya. Kuspito ortotik prostetik. Solo. [cited 2012 Apr 9]. Available from: https://Kuspito.com. 